\title{
EFFECT OF EDUCATION AND CAREER DEVELOPMENT WORK PERFORMANCE OF EMPLOYEES PT. TRAIN INDONESIA (Persero) DIVISION II REGIONAL WEST SUMATRA
}

\author{
Marinawati Amoi ${ }^{1)}$, Ramadhania ${ }^{2)}$, Lenny $\operatorname{Hasan}^{3)}$ \\ 1,2,3,)Management Department, Faculty of Economics, University of Tamansiswa , Padang \\ Correspondence Author: ramadhania010589@gmail.com
}

\begin{abstract}
This study aims to influence education and work performance on the career development of employees of PT. Kereta Api Indonesia (Persero) Regional Division II West Sumatra.The population in this study were all employees of the office environment PT. Kereta Api Indonesia (Persero) West Sumatra Regional Division II numbering 70 employees.Teknik sampling used in this study is total sampling, The data analysis used is multiple linear regression analysis. Based on the results of the research found results of multiple regression analysis is $Y=$ $0,107+0,272 X 1+0,718 X 2+e$, then t-test education variable positive and significant impact on the career development of employees of PT. Kereta Api Indonesia significant value 0,027 <0,05. Work performance variables positive effect on the career development of employees of PT. Kereta Api Indonesia with significant value 0,000 <0,05, F-test education variable and performance together have a significant effect on the career development of employees of PT. Kereta Api Indonesia with a significant level of 0,000 <0,005, Based on the results obtained by the coefficient of determination contained in the value of Adjusted $R$ Square with 0,568. This means that the ability of independent variables in explaining the dependent variable is equal to $56,8 \%$ is $43,2 \%$ explained by other variables which are not addressed in this study was the exposure, networking, loyalty to the organization, coaches and sponsors, the opportunity to grow.
\end{abstract}

Keywords: Education, Career development, Work Performance, employees

\section{Introduction}

The role of HR is indispensable for being the subject of implementing and managing operational activities. Qualified and competent human resources have the most central position in determining and carrying out the work in the company in order to achieve a goal. Each company must respond to the presence or existence of the company in the future is highly dependent on human resources capable of competence. If this is not observed, then the company can decline and excluded from other companies because of incompetence in the face of competition.

HR support is also needed by PT. Kereta Api Indonesia (Persero) Regional Division II West Sumatra. HR becomes one of the most important factors in determining the success and sustainability of PT. Kereta Api Indonesia (Persero) Regional Division II West Sumatra. PT. Kereta Api Indonesia (Persero) Regional Division II West Sumatra is a General Agency for State-owned companies (SOEs) are engaged in ground transportation services in West Sumatra which has a dual role, namely as an Agent of Development and companies that are profitable. The company has a social responsibility to organize public transportation is rail transport for all Indonesian citizens.

This is in line with the company's vision to be the best rail service providers that focus on customer service and meet the expectations of stakeholders. Therefore, the Company requires human resources that have quality, high competence and superior performance to support the achievement of that vision. It will also have a positive impact on the career development of employees are better achievement in the career of the employee. Many factors affect an employee's career, which one of them is education. Education is a basic thing that should be shared by all employees, whose activities to acquire knowledge, skills, with a view to changing individual behavior toward better and to increase the quality of human resources in order to have a wider horizon, which will affect the performance of these employees,

The higher education pursued by an employee, the higher the competency of that employee could produce better work and will have an impact on employee job performance and career development. Education can be seen from the end of the educational level of employees before they join the company, either already joined or will join. Does the employee who completed primary school, junior high school / vocational, diploma, S1, and the next 
high- level education. Furthermore, the factors that influence employee career that performance. Job performance is the result and quality of the work achieved by the standards set by a company or organization. To produce a work and good quality work and effective and efficient, the employee must have an adequate educational background and higher, because it will reflect that the employee has the knowledge, competence and comprehensive insight into the employee's career development.

Here are some types of employee career development PT. Kereta Api Indonesia (Persero) of West Sumatra Regional Division II 2018 can be seen in Table 1 are as follows:

Table 1. Employee Data PT. Kereta Api Indonesia (Persero) West Sumatra Regional Division II Year 2018 Get Career Development

\begin{tabular}{llcccc}
\hline No & & Work field & Number of & \multicolumn{2}{c}{ Information } \\
\cline { 4 - 5 } & & Employees & already & Not yet \\
\hline 1 & Vice President & 1 & 1 & - \\
\hline 2 & Procurement of goods and services & 3 & 3 & - \\
\hline 3 & Means & 6 & 4 & 2 \\
\hline 4 & Information Systems & 2 & 2 & - \\
\hline 5 & Finance and HR Manager & 1 & 1 & - \\
\hline 6 & Budget and Accounting & 4 & 4 & - \\
\hline 7 & Finance and Taxes & 4 & 3 & 1 \\
\hline 8 & HR, KRT \& Protocol and Documents & 11 & 7 & 4 \\
\hline 9 & billing & 3 & 3 & - \\
\hline 10 & Building Maintenance Department & 2 & 2 & - \\
\hline 11 & Operation & 8 & 8 & - \\
\hline 12 & security & 3 & 1 & 2 \\
\hline 13 & Infrastructure & 8 & 8 & - \\
\hline 14 & Assets and Operation Assets & 12 & 11 & 1 \\
\hline 15 & Law & 1 & 1 & - \\
\hline 16 & Public Relations & 1 & 1 & - \\
\hline
\end{tabular}

From the results of the data table 1 above, it appears there is still an employee of PT. Kereta Api Indonesia (Persero) Regional Division II West Sumatra who have not received career development. This phenomenon occurs because of the uneven provision of career development to all employees, which when held career development (training, education / training) the company, the employees who were requested to follow still the same person. So, not all employees feel the benefits of career development conducted by PT. Kereta Api Indonesia (Persero) Regional Division II West Sumatra.

If the company is lacking in attention to career development, it is likely that the company will not grow and can't compete and can't meet the primary objectives of the company. Employees still have a low educational background, as well as the rank / lower class will have difficulty in improving work performance because it does not meet the requirements to occupy a position, so that career development is necessary for employees to meet the objective of PT. Kereta Api Indonesia (Persero) Regional Division II West Sumatra.

The better the education a person has, it will affect the competences of the employees, so that employees are able to obtain the results expected good performance and achieve high performance that does not directly affect the employee's career development. Career development (training, education / training) is one way to improve the performance to get a good performance where if the performance increases, it will be considered for promotion in a higher position.

\section{Literature Review}

Human resource management is the science and art of governing the relationship and the role of labor in order to effectively and efficiently help the realization of objectives of the company, employees, and society (Hasibuan, 2016: 9).

According Sutrisno (2010: 65), education is the totality of human interaction for full human development, and education is a process that is constantly evolving. Learners is an input, after experiencing the educational process by utilizing the educational goals that resources from the existing curriculum, produce the output of certain 
capabilities, so it can be said that changes in behavior including knowledge,attitudes,actions, appearance and so on.

According Sutrisno (2012: 150), suggests understanding of job performance as proficiency someone on tasks that include job. The definition shows the weight of the individual capabilities in conformity with the provisions contained in the job.

According Mangkunegara (2017: 43), career development is staffing activities that help employees plan their future career in the company so that the company and the employee to develop maximum restraint.

According to Gomes (2010: 213), career development is a combination of the needs of training in the future and human resource planning. Namely career development activities and behaviors associated with the work and attitudes, values, and aspirations associated throughout a person's lifetime.

Hiking rationale used in this study can be illustrated in the diagram of the structure of the conceptual framework. These are presented in order to simplify and clarify the direction or the flow of education and research that affect work performance on the career development of employees of PT. Kereta Api Indonesia (Persero) Regional Division II West Sumatra. Here is an overview of the conceptual framework of this study:

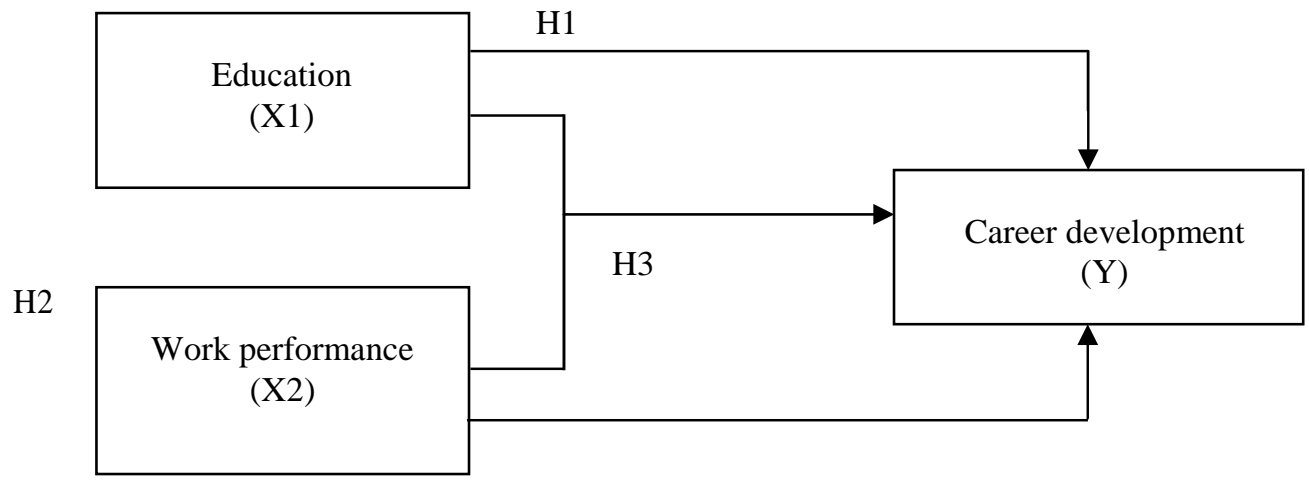

Figure 1. Conceptual Framework

\section{Research Methods}

The study used quantitative research methods. According Sugiyono (2012: 14), quantitative methods can be interpreted as a method of research that is based on the philosophy of positivism used to examine the population or a particular sample, quantitative data analysis or statistics, with the aim to test the hypothesis that has been determined. Type Quantitative methods in this research is quantitative descriptive.

According Sugiyono (2014: 81), the population is a generalization region consisting of the objects or subjects that have certain qualities and characteristics defined by the researchers to learn and then drawn conclusions. The population in this study were all employees of the office environment PT. Kereta Api Indonesia (Persero) West Sumatra Regional Division II numbering 70 employees.

According Sugiyono (2012: 118), the sample is part of a number of characteristics possessed by this population. Teknik sampling used in this study is total sampling, which the sample was taken based on the proportion of employee jobs or category field, then performed to determine the respondents.

\section{Results and Discussion}

According to Pardede and Manurung (2014: 27), It is known that in a multiple regression, the dependent variable is affected by two or more variables that relate functionally independent variables between the dependent variable (Y), with the independent variables $(\mathrm{X} 1, \mathrm{X} 2, \mathrm{Xn})$. Based on regression test carried out can be seen in Table 2 below: 
Table 2. Multiple Linear Regression Test Results

Coefficients $^{\mathrm{a}}$

\begin{tabular}{|c|c|c|c|c|c|c|}
\hline \multirow[b]{2}{*}{ Model } & & \multicolumn{2}{|c|}{ Coefficients unstandardized } & $\begin{array}{l}\text { standardized } \\
\text { Coefficients }\end{array}$ & $\mathrm{T}$ & Sig. \\
\hline & & B & Std. Error & beta & Lower Bound & Upper Bound \\
\hline 1 & (Constant) &, 107 &, 460 & &, 232 &, 817 \\
\hline & education (x1) &, 272 &, 120 & , 204 & 2,264 &, 027 \\
\hline & job performance $(\mathrm{x} 2)$ &, 718 &, 101 &, 643 & 7.139 &, 000 \\
\hline
\end{tabular}

a. Dependent Variable: development career (Y)

Based on data analysis using SPSS 20 for windows, the obtained results of the regression equation as follows:

$$
\mathrm{Y}=\mathrm{X} 1+0,107+0,272+0,718 \times 2 \mathrm{E}
$$

The regression equation above shows the relationship between independent variables and the dependent variable partially, from the equation it can be concluded that:

1) Constanta value is 0,107 means that if there is / was no change in the variables of education, and job performance, the career development of employees of PT. Kereta Api Indonesia (Persero) of West Sumatra Regional Division II fixed at 0,107 units.

2) The regression coefficient is 0,272 pales education education variable $\left(X_{1}\right)$ increased by 1 (Unit) assuming work performance variables $\left(\mathrm{X}_{2}\right)$ and constant $(\alpha)$ is 0 (zero), then the career development of employees of PT. Kereta Api Indonesia increased by 0,272 units or $27,2 \%$.

3) The regression coefficient is 0.718 job performance pales in work performance variables $\left(\mathrm{X}_{2}\right)$ increased by 1 (Unit) with the assumption that education variable $\left(\mathrm{X}_{1}\right)$ and a constant $(\alpha)$ is 0 (zero), then the career development of employees of PT. Kereta Api Indonesia (Persero) of West Sumatra Regional Division II increased by $71,8 \%$ or 0,718 units.

According Pardede and Manurung (2014: 29), tcount used to test the effect of partially (per variable) on the dependent variable. Are these variables have a significant effect on the dependent variable (Y) or not. Based on $t$ test carried out can be seen in Table 2 below:

1) Variables Influence Career Development Toward Education (H1)

Education variable (X1) significant and positive impact on the career development of employees of PT. Kereta Api Indonesia (Persero) Regional Division II West Sumatra. It can also be seen from the value of $t>t$ table with $\mathrm{df}=\mathrm{nk}=70-3=67(1,668)$, so the value of $\mathrm{t}>\mathrm{t}$ table $(2,264>1,668)$ with significant value $0,027<0,05$, then $\mathrm{Ho}$ is rejected and $\mathrm{H} 1$ accepted. This means that education variable positive and significant effect on the career development of employees of PT. Kereta Api Indonesia (Persero) Regional Division II West Sumatra.

2) Variables Influence KerjaTerhadap Achievement Career Development (H1)

Work performance variables (X2) significant and positive impact on the career development of employees of PT. Kereta Api Indonesia. It can also be seen from the value of $t>t$ table with $d f=n k=70-3=67(1,668)$, so the value of $\mathrm{t}>\mathrm{t}$ table $(7,139>1,668)$ with significant value $0,000<0,05$, then Ho is rejected and $\mathrm{H} 1$ accepted. This means that work performance variables affect positively and significantly to the career development of employees of PT. Kereta Api Indonesia (Persero) Regional Division II West Sumatra.

According Pardede and Manurung (2014: 28), F test can be used to simultaneously test the effect of independent variables on the dependent variable (Y). If the independent variables have simultaneous effect on the dependent variable (Y), then the regression model qualifies as suitable or fit. Based on the results of tests performed can be seen in Table 3 below:

Table 3. The Results of $F$ test (simultaneous) ANOVA $^{\mathrm{b}}$

\begin{tabular}{llrrrrr}
\hline Model & & Sum of Squares & Df & mean Square & F & Sig. \\
\hline 1 & Regression & 11.852 & 2 & 5,926 & 46.349 &, $000 \mathrm{a}$ \\
& residual & 8.567 & 67 &, 128 & & \\
& Total & 20.419 & 69 & & & \\
& & & & \\
\hline
\end{tabular}

a Predictors: (Constant), performance (x2), education (x1) b

Dependent Variable: career development (Y) 
Based on the test results in the table above can be seen in the value of 46,349 with value Fhitung Ftabel df1 $=\mathrm{k}-1=3-1=2, \mathrm{df} 2=\mathrm{nk}(70-3=67)$ was 3,13 so the value of $\mathrm{F}$ count $>\mathrm{F}$ table or $46,349>3,13$, with a significant level of $0,000<0,005$, then $\mathrm{Ho}$ is rejected and accepted H3. It can be concluded that education and job performance variables simultaneously significant effect on the career development of employees of PT. Kereta Api Indonesia (Persero) Regional Division II West Sumatra.

According Ghozali (2012: 97), the coefficient of determination (R2) is a tool to measure how far the model's ability to explain variations in the dependent variable. Coefficient of determination is between zero or one. R2 small value means the ability of independent variables in explaining the variation of the dependent variable is very limited. Adjusted R2 has a value ranging between $0 \leq \mathrm{R} 2 \leq 1$. Based on tests conducted R2 can be seen in Table 4 below:

Table 4.Test Coefficient of Determination Model Summary ${ }^{\mathrm{b}}$

\begin{tabular}{lcccc}
\hline Model & $\mathrm{R}$ & $\mathrm{R}$ Square & adjusted R Square & Std. error of the Estimate \\
\hline 1 &, 762 &, 580 &, 568 &, 35758 \\
\hline
\end{tabular}

a. Predictors: (Constant), performance (X2), education (X1)

b. Dependent Variable: career development (Y)

Based on Table 4, to note that the coefficient of determination contained in the value of Adjusted R Square with 0,568 . This means that the ability of independent variables in explaining the dependent variable was $56,8 \%$ while the remaining $43,2 \%$ is explained by other variables that are not addressed in this study was the exposure, networking, loyalty to the organization, mentor and sponsor, the opportunity to grow.

\section{Conclusion}

Conclusions from the study of education and work performance on the career development of employees of PT. Kereta Api Indonesia (Persero) West Sumatra Regional Division II are as follows:

1. The results of multiple regression analysis is $Y=0,107+0,272 X_{1}+0,718 X_{2}+e$. From the equation it can be concluded that:

a. Constanta value is $=0,107$ means that if there is / was no change variables of education, work performance (value $\mathrm{X}_{1}$ and $\mathrm{X}_{2}$ ) is 0 (zero) then the career development of employees of PT. Kereta Api Indonesia (Persero) of West Sumatra Regional Division II fixed at 0,107 units.

b. Values education is the regression coefficient $=0,272$ pales education variable $\left(\mathrm{X}_{1}\right)$ increased by 1 (Unit) assuming work performance variables $\left(\mathrm{X}_{2}\right)$ and constant $(\alpha)$ is 0 (zero), then the career development of employees of PT. Kereta Api Indonesia (Persero) of West Sumatra Regional Division II increased by 0,272 units.

c. Work performance regression coefficients are $=0,718$ pales job performance variables $\left(\mathrm{X}_{2}\right)$ increased by 1 (Unit) assuming education variable $\left(\mathrm{X}_{1}\right)$ and a constant $(\alpha)$ is 0 (zero), then the career development of employees of PT. Kereta Api Indonesia (Persero) of West Sumatra Regional Division II increased by 0,718 units.

2. T Test Results

a. Education variable $\left(\mathrm{X}_{1}\right)$ positive and significant impact on the career development of employees of PT. Kereta Api Indonesia (Persero) Regional Division II West Sumatra. This is evidenced by the value of $t>t$ table $(2,264>1,668)$ with significant value $0,027<0,05$.

b. Work performance variables $\left(\mathrm{X}_{2}\right)$ positive effect on the career development of employees of PT. Kereta Api Indonesia (Persero) Regional Division II West Sumatra. This is evidenced by the value of $\mathrm{t}<\mathrm{t}$ table $(7,139>1,668)$ with significant value $0,000<0,05$.

3. Test Results Variable educational $F\left(X_{1}\right)$ and performance $\left(X_{2}\right)$ together have a significant effect on the career development of employees of PT. Kereta Api Indonesia (Persero) of West Sumatra Regional Division II with a value of $\mathrm{F}>\mathrm{F}$ table or 46,349 $>3,13$, with a significant level of $0,000<0,005$

4. Based on the results obtained by the coefficient of determination contained in the value of Adjusted R Square with 0,568 . This means that the ability of independent variables in explaining the dependent variable was $56,8 \%$ remaining $43,2 \%$ is explained by other variables that are not addressed in this study was the exposure, 
networking, loyalty to the organization, mentor and sponsor, the opportunity to growth.

\section{Suggestion}

Conclusions based on the results above, it can be put forward suggestions of this study are as follows in order for an employee at PT. Kereta Api Indonesia (Persero) Regional Division II West Sumatra increaseability to work, because employee they tend to make adjustments to the work given to able to be completed as well and the ability is still quite good employee. In order for managers and employees at PT. Kereta Api Indonesia (Persero) Regional Division II West Sumatra regard to work employees to be adjusted employee skills and abilities in terms of both education and work performance. For future research it is advisable to add variables related to career development, besides this study can be used as reference material.

\section{References}

Agus Dwi Nugroho, and Kunartinah. (2012). Analysis and Development Career Compensation Effect on Job Satisfaction with Mediation Work Motivation. Journal of Business and Economics. Vol.19, No.2.

Dawn, Siti Al and Heru, Tri. (2010). Human Resource Management as the Basis for Achieving Competitive Advantage. Yogyakarta: College of Management Sciences YKPN.

Garnida, D. (2017). Effect of Education, Work Experience and Job Performance Against Employee Career Development in the Public Works Department of East Kutai. Government eJurnal integrative, Hal. 626635.Rineka Notices.

Ghozali, Imam. (2012). Applications Multivariate Analysis with IBM SPSS Program. Yogyakarta: Diponegoro University.

Gomes, Faustino Cardoso. (2010). Human Resource Management. Yogyakarta: Andi Offset.

Hasibuan, Malay SP. (2016). Human Resource Management. Revised Edition. Jakarta: PT. Earth Literacy. Mangkunegara, Anwar King. (2017). Human Resource Management Company. Bandung: Rosda.

Moekijat. (2010). The Management Development and Motivation. Bandung: PT. Pioneers Jaya.

Notoatmodjo, S. (2015). Health Research Methodology. Jakarta: Rineka Reserved.

Onibala, NR, Tewal, B., \& Sendow, GM. (2017). Influence of Education, Training and Career Development Against Employee Performance On State Property Office and Auction Manado. EMBA Journal Vol. 5, p. 2790- 2798.

Pardede, Ratlan and Manurung, Renhard. (2014). Analysis of Line (Path Analysis) Theory and Applications in Business Research. Jakarta: Rineka Reserved.

Sugiyono. (2017). Quantitative Research Methods, Qualitative and $R \&$ D. Bandung: PT. Alfabeta.

Susanto, P, \& Sari, RD. (2013). Effect of Education and Work Performance Against Employee Cooperative Career Development At Large Families PT. Semen Padang. Business Management Studies Journal Volume 2 No. March 2. P. 57-71.

Sutrisno, Edy. (2012). Financial Management Theory, Concepts and Applications. Yogyakarta: Ekonisia.

Suwanto and Priansa. (2011). Human Resource Management in Public Organization and Business. Bandung: PT. Alfabeta. 